\title{
Debt Conservatism and Debt-Equity Choices: Evidence from REITs' Unused Debt Capacity
}

\author{
Woei-Chyuan Wong
}

Universiti Utara Malaysia, Malaysia

wwchyuan@uum.edu.my

\section{A R T I C L E I N F O}

Article history:

Received 11 October 2017

Revised form 14 March 2018

Accepted 15 March 2018

Keywords:

Capital structure, Financial

flexibility, Unused debt capacity, REIT

JEL Code: G32

\section{A B S T R A C T}

We infer debt conservatism behavior by examining how REITs adjust towards their debt capacity following a capital issue or repurchase decision. It is observed that REITs with high unused debt capacity tend to issue equity which renders them more underleveraged for at least two consecutive years. These high debt buffer REITs also tend to converge slowly towards their debt capacity through repurchase decisions and hold significantly higher unused debt facilities than their low buffer counterparts. These findings are robust to a variety of robustness checks and cannot be explained by the traditional pecking order and trade-off theories of capital structure.

\section{Introduction}

Debt conservatism refers to a situation where firms maintain a significantly lower debt ratio than the optimal debt ratio predicted by the trade-off theory of capital structure (Strebulaev \& Yang, 2013; Graham, 2000; Myers, 1984). Strebulaev and Yang (2013) showed that, on average, 10.2\% of the US firms during the period 1962-2009 did not have a single debt on their balance sheet. Moreover, this phenomenon is persisting whereby $30 \%$ of zero leverage firms remain debt free for at least five consecutive years. What is striking is that these zero leverage firms tend to be profitable, pay high taxes and have high cash balances. Similarly, Graham (2000) also showed that firms that maintain low 
leverage tend to be large, profitable, liquid, in stable industries, and face low ex-ante costs of distress. ${ }^{1}$ This suggests that the low leverage phenomenon is a deliberate action of firms not due to their financial constraint status or credit rationing imposed by the lenders.

This low leverage puzzle does not go unchallenged. One strand of literature argues that firms, in fact, do not underleverage with respect to their predicted debt ratio generated from contingent claim models (Morrellec, 2004 and Ju et al., 2005) and dynamic trade-off models (Hennessy \& Whited, 2005 and Strebulaev, 2007). Others claim that the tax benefits from incurring debt might not be that high as implied by the trade-off theory when adjusted for the cost of financial distress (Molina, 2005) and non-tax debt shield (Graham \& Tucker, 2006). Minton and Wruck (2001) concluded that debt conservatism is transitory after observing that $70 \%$ of firms dropped their conservative policy over the 10 year period. Another strand of literature attempted to explain debt conservatism as a rationale decision driven by the need to preserve future financial flexibility for potential investments or financing them with risky securities (Fama \& French, 2002), saving for future financing needs (Viswanath, 1993 and Lemmon and Zender, 2010), or having an option to increase leverage (Goldstein, Ju, \& Leland, 2001).

In this paper, we complement the literature on underleveraged phenomena by examining how firms adjust towards or away from their debt capacity when issuing or repurchasing securities. Controlling factors known to affect firms' debt-equity choice, findings of equity issues by firms with high unused debt capacity will support debt conservatism behavior because these new issues tend to push firms away from their debt capacity that make them more underleveraged. Focusing on unused debt capacity also allows us to contrast our hypotheses with extant capital structure theories that carry the opposite predictions with respect to the relationship between unused debt capital and debt-equity choice. These theories predict a positive (negative) relationship between debt (equity) issue and unused debt capacity. In other words, firms tend to issue securities that make them converge closer to their debt capacity or optimal debt ratio.

The crux of our empirical strategy is the availability of debt capacity measure which is unobservable in practice. For this reason, we focus on samples of Malaysia and Singapore REITs with observable debt capacity proxied by the regulatory debt limit. This regulatory debt limit is the maximum attainable debt limit by REITs in these countries. This debt limit is binding since breaching of this regulatory gearing would result in REITs losing their tax-exempt status. The regulation does provide some flexibility for REITs to temporarily exceed their debt limit due to transient falls in asset value. ${ }^{2}$ The debt limit was not constant during the sample period due to the exogenous regulatory limit increase from $35 \%$ to $50 \%$ (for Malaysian REITs in August 2006) and 60\% (for Singapore rated REITs in November 2005). Singapore REITs during the study period were subjected to two-tier debt limits, i.e. $60 \%$ for rated REITs and 35\% for unrated REITs. Effective from Jan $1^{\text {st }} 2016$, the Singapore REIT sector has adopted a 
single $45 \%$ debt limit. This observable and heterogeneity debt capacity provided "an advantage point to our empirical setting". Unlike previous literature that relied on indirect approaches to estimate debt capacity, we could directly observe the impact of unused debt capacity on capital structure decisions. The deviation of the actual debt ratio from its regulatory debt capacity is explicitly mentioned in the Asian REITs' annual report as an important consideration in their capital structure and investment decisions. ${ }^{3}$

Apart from its observable debt capacity, REITs' institutional framework makes the traditional capital structure theories less important in explaining capital offering choices. Firstly, REITs do not pay corporate taxes. Thus, the trade-off theory's tax based explanation to debt usage becomes irrelevant for the REIT sector. Jensen's (1986) agency costs explanation for using debt is also less important as there is not much free cash flow at REIT managers' disposal in the first place due to REIT's high distribution requirement. Lastly, the pecking order explanation is also incomplete since the internal funds are absent from REITs' financing choices. Moreover, REITs' frequent trips to capital market for equity and debt funding also make information sensitivity of financing choices (begins with internal funds, then safe debts and finally equity) as postulated by the pecking order theory to become less important for REITs than the general companies.

We found support for debt conservatism behavior where high debt buffer REITs tend to issue equity that makes them further deviate from their debt capacity. This main result is robust to a battery of robustness check implying that debt conservatism is the first order priority in capital offering choices. We further showed that this debt conservatism behavior persists for a period of at least 2 years and is driven by firms operating below their optimal debt ratio. We do observe debt convergence in repurchasing decisions. The adjustment pattern is asymmetric where high buffer REITs adjust at a slower pace towards their debt capacity compared to low buffer REITs. This debt conservatism behavior is not influenced by proxies to corporate liquidity/financial constraints and could not be explained by trade-off and pecking order theories. Underscoring the importance of controlling for debt capacity in this study, we showed that we would have wrongly concluded our results as being driven by aggressive debt policy had we replaced the debt buffer variable with the actual debt ratio.

Our paper broadly contributes to capital structure literature by explicitly taking into consideration the deviation of individual REIT's actual debt ratio from their debt capacities. The two boundaries of debt capacities used in this paper also serve to differentiate whether REITs' debt ratios converge towards their optimal debt capacity (trade-off theory) or regulatory debt capacity (pecking order theory). Existing papers are generally silent on the roles of debt capacity on capital structure decisions. In the case of REITs, for instance, Harrison et al. (2011) assumed that high debt ratio is an indication of high debt capacity while Riddiough and Steiner (2018) related high debt ratio with low debt capacity. ${ }^{4}$ 
As pointed out by Lemmon and Zender (2010) these assumptions are prone to misclassification of firms with large debt capacity but high current leverage as being financially flexible or firms with small debt capacity but little or no leverage as being financially constrained.

The rest of this article proceeds as follows. The next section presents a review of the literature followed by an outline of the research design and data in the third section. The fourth section discusses the empirical results with a focus on the impact of unused debt capacity on REITs' capital offering choices while the fifth section provides the conclusion.

\section{Literature Review}

The literature on firms' debt-equity choice is well researched. One strand of these papers examines the impact of unused debt capacity on firms' debt equity choices. Focusing on unused debt capacity allows researchers to put these traditional pecking order and trade-off theory on a "horse race". This is because the distance between firms' actual debt ratio and their debt capacity underpins the predictions of both the trade-off and pecking order theories. Firms, according to the trade-off theory, should issue debt as long as they are operating below their optimal debt ratio. In the case of the pecking order theory, firms should issue debt rather than equity as long as they are operating below their debt capacity. Myers' (1977) pecking order theory theorized that high growth firms strive to maintain financial slack to avoid issuing equity to meet their future financing needs. Financial flexibility, a relatively new explanation to firms' debt-equity choice, prescribed that firms deliberately preserve, drawdown and replenish their financial flexibility over time (DeAngelo, DeAngelo, \& Whited, 2011, Byoun, 2011). This hypothesis also predicts that firms with higher unused debt capacity issue more debt in the future.

De Jong et al. (2011) concluded from their sample of US firms that the pecking order theory better describes firms' issuance decisions where firms that exceeded their optimal debt ratio continue increasing leverage until the debt capacity is reached. This runs contrary to the trade-off theory's prediction that firms should not incur further debt once they reach their optimal debt ratio. Similarly, Hess and Immenkotter (2014) also found the unused debt capacity to be positively related to net debt issues. They however, interpreted this result as supportive of financial flexibility where firms with high unused debt capacity tend to issue more debt. In order to distinguish their results from the trade-off theory explanation, they showed that firms reaching their debt capacity and with a financing surplus tend to issue equity or pay off debt. This is consistent with the financial flexibility motive but inconsistent with the trade-off theory's prediction of no debt reduction since firms already are at their optimal debt 
ratio. In sum, both financial flexibility and the traditional trade-off/pecking order theories predict a positive relationship between unused debt capacity and debt issues.

As mentioned before, the literature on debt conservatism focuses on the extent of underleverage from optimal debt ratio and explains why firms are willing to forgo tax benefits of debt. The papers closely related to this study are "those on corporate leverage stability". Lemmon, Roberts and Zender (2008) showed that corporate leverage is remarkably stable over time; firms with relatively high (low) leverage tend to maintain them for over 20 years. One implication of the financial stability phenomenon is that the firms' future offering decisions are closely related to their previous leverage ratio. Financial stability predicts that firms are less likely to issue material debt if their unused debt capacity was high in the earlier period. This is because high buffer (low leverage) firms tend to remain so in the near future by issuing a low level of debt. This prediction runs contrary to the predictions of the traditional trade-off/pecking order theories and the financial flexibility hypothesis discussed above.

Lemmon et al. (2008) did not however, examine whether the relationship between initial leverage and future debt issues is symmetric across high and low debt ratios. That is, whether the debt stability phenomenon is driven by low leverage firms that choose to become less leveraged (conservative) over time by issuing less debt or by high leveraged firms that become more leveraged (aggressive) by issuing more debts. A recent study by DeAngelo and Roll (2015) showed that debt persistency or stability arises mainly at low leverage and is transitory in nature. According to De Angelo and Roll (2015) firms that kept a stable debt ratio regime (within $+/-5 \%$ bandwidth) continuously for 20 years were those with a median debt ratio of less than 0.1 . These stable regimes are however, not common ( $4.2 \%$ of total firms) since for most firms, the debt stability phenomenon declines sharply over a 5-10-year horizon. Tracking the practice of conservative debt leverage policy, Minton and Wruck (2001) documented that $46.8 \%$ discontinue their conservative financial policy within a period of five years.

In this paper, we attempted to relate the literature on debt conservatism with debt equity choices by focusing on the impact of unused debt buffer on debt-equity choices. We complement Lemmon, Roberts and Zender (2008) by controlling for individual firms' unused debt capacity. Unlike previous studies that relied on indirect methods to derive debt capacity, we used the regulatory debt limit which is observable to financial managers' ex-ante. ${ }^{6} \mathrm{We}$ inferred conservatism behavior in debt equity choices based on the difference in direction and speed of the adjustment process between high and low debt buffer REITs. Our approach allowed us to construct competing hypotheses to distinguish conservatism motives from the existing theories discussed above. We also supplemented our results with the influence of optimal debt ratio and controlling for proxies for corporate liquidity. 


\section{Research Design and Data}

\subsection{Unused Debt Capacity Measures}

We measured individual REITs unused debt capacity as the difference between its regulatory debt limit and actual debt ratio. This unused debt capacity or debt buffer measures flexibility or financial slack because it indicates how much additional debt a REIT could issue before reaching its regulatory debt limit. The amount of buffer kept by individual REITs also reflects their debt policies. Conservative REITs tend to keep higher debt buffer and it is vice versa for aggressive REITs. We also considered a second debt boundary, i.e. optimal debt ratio that is widely used in the literature. Optimal debt ratio is the predicted value of debt ratios on a set of trade-off variables which includes firm size, firm age, profitability and growth opportunities (MB ratio).

\subsection{Empirical Specification}

Following Hovakimian et al. (2001) and de Jong et al. (2011), we estimated a binary logit model with marginal financing decisions (Marginal) as a function of unused debt capacity. This Marginal variable is equal to one for debt issues and zero for equity issues. We use quarterly changes in balance sheet information to identify debt and equity issues/repurchases. Equity issues (repurchases) are defined as increase (decrease) in total capital stock (exclude retained earnings) while debt issues (repurchases) correspond to increase (decrease) in total debt. The following filters were applied so that only material events were included in the sample of financing activities: The sum involved must, firstly, be larger than US \$5million and the amount must also constitute more than $1 \%$ of the REIT's total assets. Cases where REITs issued (repurchased) both debt and equity issues were omitted.

The estimated logistic model is as follows:

$$
\begin{aligned}
& \text { Marginal }_{i t}=\alpha_{1}+\alpha_{2} \text { Debt buffer } r_{i t-1}+\theta \boldsymbol{X}_{i t-1}+\varphi \boldsymbol{M}_{i t}+ \\
& \boldsymbol{P}_{i}+\boldsymbol{Y}_{t}+u_{i t}
\end{aligned}
$$

where $\mathbf{X}_{\mathrm{it}-1}$ and $\mathbf{M}_{\mathrm{it}}, \mathbf{P}_{\mathrm{t}}, \mathbf{Y}_{\mathrm{t}}$ are the vectors of firm characteristics, market timing variables, property and year dummies respectively, and $\mathrm{u}_{\mathrm{it}}$ is the residual assumed to be serially uncorrelated with mean zero. The vector $\mathrm{X}$ contains the controls for the traditional capital structure determinants such as cash holding, firm size, firm age, growth opportunities, profitability and asset tangibility. Vector M, on the other hand, controls for market timing behavior including past stock returns, 
interest rate and term structure. These variables capture financial managers' market timing behavior by taking advantage of the relative costs of debt and equity capital in raising capital. We mitigated the reverse causality concern by lagging all firm-level explanatory variables. The construction of all of the variables used in this study is detailed in Appendix A. The correlation matrix in Appendix B indicates minimal problem with multicollinearity.

We only elaborate here the predictions for issuing decisions since the predictions of repurchasing decisions follow the same logic albeit with the opposite sign. Traditional capital structure theories (pecking order and trade-off) and financial flexibility predict a positive $\alpha_{2}$ where REITs with higher unused debt buffer in the previous period are more likely to issue debt in the current period. This is consistent with the idea of debt convergence towards either an optimal debt ratio (trade-off) or debt capacity (pecking order). The financial flexibility hypothesis also predicts a positive coefficient $\alpha_{2}$ indicating REITs make use of the financial slack (debt buffer) they preserved in the previous period to issue more debt in the current period. A negative $\alpha_{2}$ in hand is consistent with the prediction of financial stability where firms that maintain a lower (higher) debt buffer in the previous period tend to remain as such in the next by issuing lesser debt (higher equity).

In order to discern debt conservatism behavior, we allowed for the differential of $\alpha_{2}$ in Equation (1) to vary between high and low debt buffer subsamples. The specification is as below:

$$
\begin{aligned}
& \text { Marginal }_{i t}=\alpha_{1}+\alpha_{2} \text { Debt buffer } \\
& \alpha_{3} \text { Debt buffer }_{i t-1} D_{t-1} D_{t-1}^{\text {Ligh buffer }}+
\end{aligned}
$$

where $D_{t-1}$ High buffer $\left(D_{t-1}\right.$ Low buffer $)$ is a dummy variable equal to one if debt buffer is above (below) the median value of debt buffer in the sample and zero otherwise for REIT $i$ at time $t$ - 1 . The signs of coefficients $\alpha_{2}$ and $\alpha_{3}$ indicate whether REITs are moving towards or away from their target debt ratio. The basic premise of debt conservatism behavior is that firms would opt for financing choices that make them deviate further (below) from their debt capacity, hence, making them carry more unused debt capacity. Empirically, we expect REITs with higher debt buffer to either deviate more from their debt capacity than low buffer REITs $\left(\alpha_{2}<0 \& \alpha_{2}<\alpha_{3}\right)$ or to converge at a slower rate than their low buffer counterparts towards debt capacity $\left(\alpha_{2}>0 \& \alpha_{2}<\alpha_{3}\right)$. Notice that we did not require REITs to adjust until they reached the debt capacity since this is maximum debt boundary of debt ratio. A move towards or away from debt capacity would suffice for us to infer debt conservatism behavior. 


\subsection{Data}

Our sample was a quarterly panel data set of Singapore and Malaysian listed REITs during the period 2003 to 2015 . The financial data and stock prices used in this research were obtained from Bloomberg's database. Individual REIT's unused debt facilities were extracted from annual reports and converted to quarter using the linear interpolation method. ${ }^{7}$ We avoided survivorship bias by including both active and delisted REITs that appeared in Bloomberg's database. ${ }^{8}$ The variables used in the regression analysis were winsorized at the $1^{\text {st }}$ and $99^{\text {th }}$ percentile to avoid the influence of extreme observations. After omitting observations with missing values REITs, the unbalanced panel data consisted of 1344 firm-quarter observations covering 54 REITs publicly traded between 2003:Q1 and 2015:Q4. This sample contained a total of 569 security issues and 475 security repurchases defined as in Hovakimian et al. (2001) and de Jong et al. (2011) mentioned above.

\subsection{Summary Statistics}

Table 1 presents the descriptive statistics for all variables used in this study. On average, REITs are less likely to issue $(45.0 \%)$ and repurchase $(40.6 \%)$ debt than equity. The prevalence of equity issues despite the fact that all REITs are operating below their regulatory capacity provides a crude test to reject the pecking order theory which hypothesizes firms to issue equity only when they have used up their debt capacity. Regulatory buffer is distributed symmetrically across the sample of REITs with the sample mean and the median equal to $22.2 \%$ and $23.1 \%$ respectively of the total assets on the back of the average regulatory debt limit of $52.3 \%$. Our measure of debt buffer was higher than the estimated buffers of $16.2 \%$ and $17.2 \%$ reported by, respectively, de Jong, Verbeek and Verwijmeren (2012) and Hess and Immenkotter (2012) using credit rating regression models. The mean debt ratio of $30.1 \%$ was substantially lower than 52\% documented by Giacomini et al. (2017) for US REITs for the period 1990-2012. The average optimal debt ratio of $29.6 \%$ indicated firstly, REITs were operating near their optimal debt limit and secondly, optimal limit was the first debt boundary for REITs before the regulatory limit which was the maximum boundary.

Unused private and public debts constituted of $4.6 \%$ and $13.8 \%$ of the total assets respectively. The mean cash holdings were low at $2.7 \%$ while tangible assets were high at $92.4 \%$ of REITs' total assets due to the regulatory structure of REIT. The average firm size was US $\$ 1.52$ billion. REITs in our sample were relatively young with an average age of 5.3 years as REIT sector only began to flourish in Asia in the early 2000s. The average Tobin's, a proxy to firm value was approximately 0.81 times with a range of 0.37 to 1.29 . In 
terms of profitability, a typical REIT averaged $1.5 \%$ (6.0\% p.a.) as measured by ROA. As for the market timing variables, the average stock performance of $6.1 \%$ represented the price appreciation of individual REIT stocks over the last six months. Term structure spread averaged $1.4 \%$ implying an upward sloping yield curve. The relative interest rate of 1 time over the average interest rate in the past one year implied a generally stable interest rate regime.

Table 1. Descriptive Statistics

\begin{tabular}{lccccc}
\hline & Mean & Median & Std.Dev & Min. & Max. \\
\hline Capital Offerings & & & & & \\
Debt-equity issues & 0.450 & 0 & 0.498 & 0 & 1 \\
Debt-equity repurchases & 0.406 & 0 & 0.492 & 0 & 1 \\
Debt Variables & & & & & \\
Debt buffer & 0.222 & 0.231 & 0.109 & -0.037 & 0.600 \\
Debt limit (capacity) & 0.523 & 0.500 & 0.090 & 0.350 & 0.600 \\
Debt ratio & 0.301 & 0.319 & 0.102 & 0 & 0.579 \\
Optimal debt ratio & 0.296 & 0.299 & 0.053 & 0.128 & 0.441 \\
Unused private debts & 0.046 & 0.021 & 0.063 & 0 & 0.297 \\
Unused public debts & 0.138 & 0 & 0.212 & 0 & 0.884
\end{tabular}

Firm Characteristics

\begin{tabular}{lccccc} 
Cash holdings & 0.027 & 0.018 & 0.031 & 0.000 & 0.196 \\
REIT size & $1,520.50$ & 990.00 & $1,610.61$ & 39.52 & $8,094.89$ \\
REIT age & 5.310 & 4.704 & 3.690 & 0.499 & 21.022 \\
Tobin's $Q$ & 0.806 & 0.822 & 0.182 & 0.366 & 1.287 \\
ROA & 0.015 & 0.011 & 0.020 & -0.056 & 0.115 \\
Asset tangibility & 0.924 & 0.957 & 0.110 & 0.397 & 0.996 \\
Market Timing & & & & & \\
Stock performance & 0.061 & 0.046 & 0.219 & -0.514 & 0.915 \\
Term structure & 1.400 & 1.256 & 0.551 & -0.045 & 2.650 \\
Interest rate & 0.999 & 1.049 & 0.351 & 0.108 & 2.343 \\
\hline
\end{tabular}

Note. The descriptive statistics for the explanatory variables was based on a full sample of 1344 firmquarter observations with 54 individual REITs. Total observations for unused private and public debts were 1,276 each due to missing value problem. Except for actual debt ratio, debt buffer and optimal debt ratio, all control variables are winsorized at the bottom and top $1 \%$ level. We used the logarithm of REIT size and REIT age for regression analysis.

Figure 1 presents the time series evolution of the average debt ratio and debt limit during Q1:2003 to Q4:2015. We observed a dramatic surge in debt buffer from $8.8 \%$ in 2004 to $21.0 \%$ in 2006 due to an increase in the regulatory 
debt limit for REITs in Singapore and Malaysia from 35\% to 60\% (for rated REITs) and $50 \%$, respectively. REITs clearly chose to maintain debt ratio at a range which was comfortably well below the regulatory debt limits so that they could access external financing without any constraints. The relatively stable debt ratio masked REITs' deliberate actions in enlarging their debt capacity. Four out of six Singapore REITs obtained credit rating within 1 year after the regulatory limit change in 2005 to tap into the additional debt capacity afforded by the existence of a credit rating. Moreover, $44 \%$ of rated Singapore REITs that had the option to leverage up to $60 \%$ chose to keep their leverage ratio below the first hurdle of $35 \%$ as in Dec 2015.

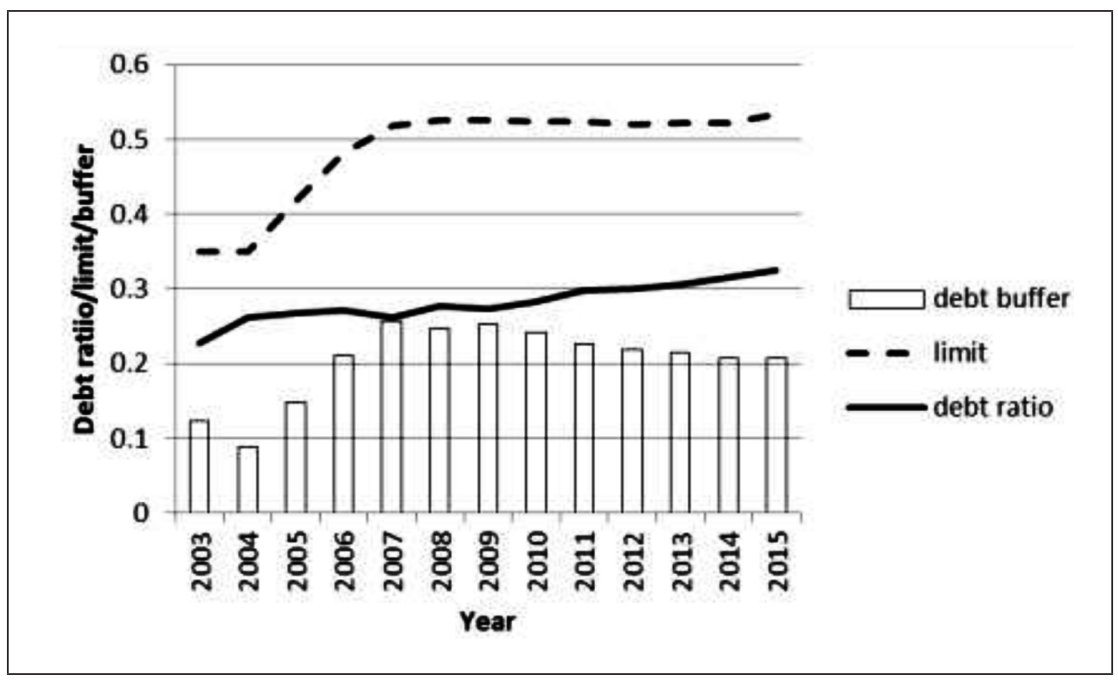

Figure 1. The Evolution of Debt Ratio and Regulatory Debt Limit

Figure 2 shows that high buffer REITs (above sample median) consistently maintain higher unused private debt capacity (mainly bank lines of credit) than low buffer REITs (below sample median) every year during the sample period. This reflects over-conservatism in debt policy since REITs need to pay annual fees (based on total lines size) and commitment fees (based on unused private debt) for maintaining this standby facility (Hardin and Hill, 2011). These results also suggest REITs that keep a higher debt buffer are not constrained in their access to external financing. In other words, low leverage is not an outcome of credit rationing by the lenders.

We also observed similar pattern in unused public debts in Figure 3. Except for years 2006, 2011 and 2012, unused public debts were higher for high buffer REITs than low buffer REITs. Not reported here, the mean test of difference for unused private/public debts was significant at the $5 \%$ level between 
the high and low buffer subsamples. Note that we only showed in Figures 2 and 3 unused private and public debts from year 2005 onwards since there was no observation for subsample above the sample median debt buffer for years 2003 and 2004. In sum, these descriptive results suggest debt conservatism behavior where REITs prefer to operate significantly below their regulatory debt limit and at the same time, maintain a huge sum of unused debt facilities to back this unused debt capacity.

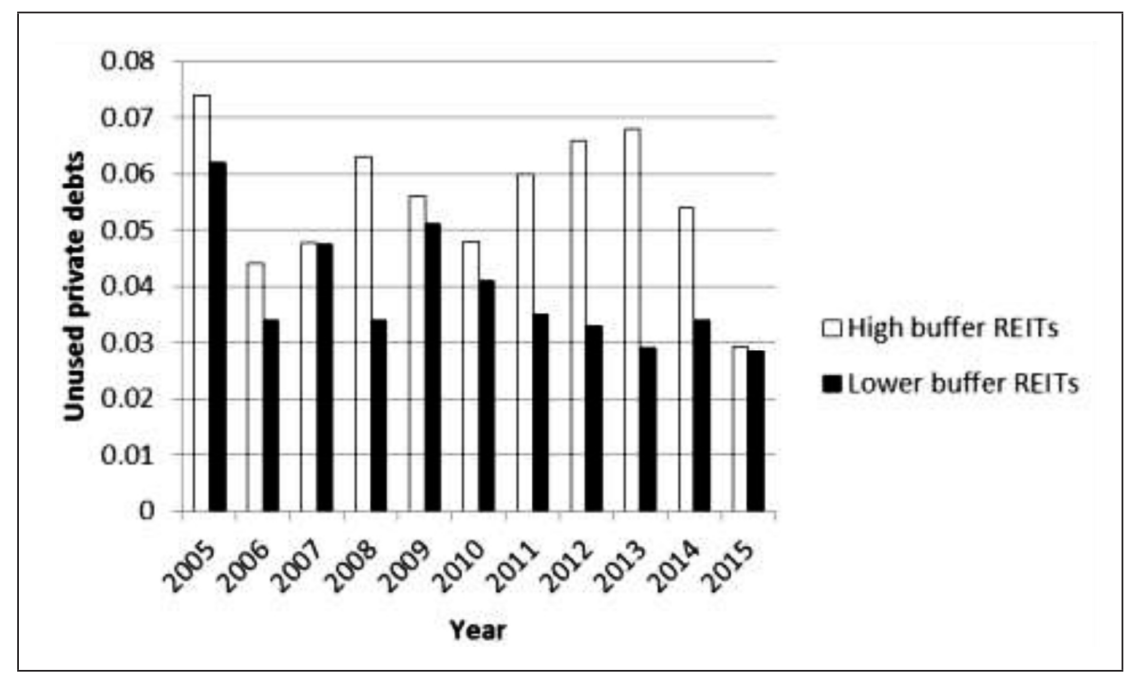

Figure 2. Unused Private Debts by Debt Buffer

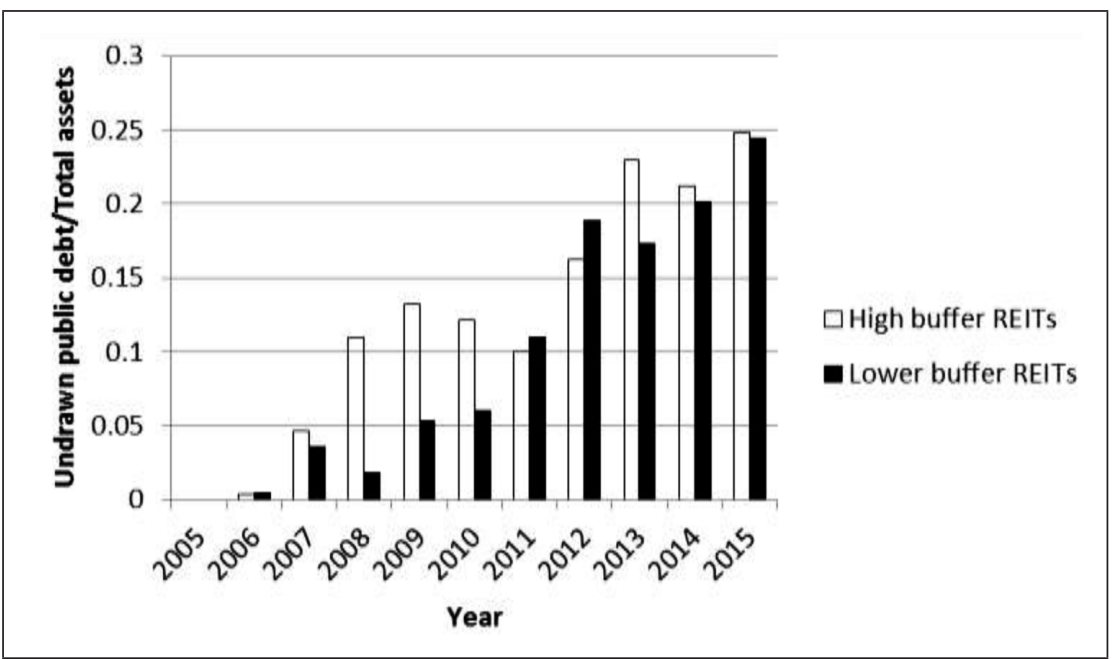

Figure 3. Undrawn Public Debts by Debt Buffer 


\section{Results}

\subsection{Main Findings}

Table 2 presents the results of the logit regressions. Robust t-stats clustered by firms (Peterson, 2009) are reported in parentheses below the regression coefficients. Models 1-2 are debt-equity issue regressions while Models 3-4 are debt-equity repurchase regressions. Model 1 shows a strong significant negative (positive) relationship between debt (equity) issues and debt buffer. This finding provides strong evidence against the trade-off/pecking order/financial flexibility theories that predict a positive relationship between the probability of debt issue and previous period debt buffer. This finding is however, in line with Lemmon et al.'s (2008) financial stability hypothesis which posits that firms that carry low leverage (high buffer) tend to remain as such by issuing more equity (debt) in the future. In REITs, Harrison et al. (2011) also documented a negative relationship between lagged leverage and debt ratio and debt issuance events which the authors interpret as evidence of substantial level of stability within a REIT's capital structure from period to period.

Model 2 examines whether the impact of debt buffer on debt-equity choice is symmetric between high and low buffer REITs. We do this by decomposing debt buffer variables into those that are above sample median (Debt Buffer ${ }_{t-1}{ }^{*} D$ high buffer) and those that are below sample median (Debt Buffer ${ }_{t-1} * D^{\text {Low buffer }}$. The coefficient of Debt Buffer ${ }_{t-1}{ }^{*} D^{\text {high buffer }}$ is negative and strongly significant while the coefficient of Debt Buffer ${ }_{t-1}^{*} D^{\text {Low buffer }}$ is insignificant. These results suggest that the deviation from debt capacity is driven by high buffer REITs that chose to issue equity over debt, making them more underleveraged rather than by low buffer REITs that aggressively issue debt which push them nearer to their debt capacity.

With regard to repurchasing decisions in Model 3 , the negative coefficients of debt buffer variables suggest debt convergence towards the debt capacity. Hovakimian et al. (2001) also found firms moving towards their target debt ratio via repurchase instead of issuing decisions. These authors suggest that firms have more discretion when repurchasing existing capital than in raising new capital. This might be relevant to the REITs sector that is known to use bank lines of credit or equity to finance investment and subsequently refinance these debt/equity with public debt of longer maturity when the timing and pricing is right (Brown \& Riddiough, 2003; Ooi et al., 2012). Repurchase decisions are therefore, likely used by REITs to reconfigure firm capital structure, while issuing decisions are driven by investment needs. This conjecture is supported by the positive and significant MB ratio, a proxy to growth opportunities that is positive and significant in issuing decisions but not in repurchasing decisions. Model 4 shows that convergence is larger in magnitude for low buffer REITs 
than high buffer REITs suggesting that high buffer REITs move much slowly towards their debt capacity compared to their low buffer counterparts. ${ }^{9}$

Three out of the four control variables are significant in the issuance equation and are in the direction predicted by the trade-off theory where financially constrained REITs (smaller, younger and lesser cash holdings) prefer to issue more equity over debt to avoid the cost of financial distress. The positive and significant coefficient of MB ratio is in line with the pecking order's prediction that firms with the greatest degree of information (high growth opportunity) have incentives to issue debt over equity. Market timing variables (stock performance, term structure and interest rate) do not exert significant influence on issuance choices though the signs are consistent with the implication of this theory. Specifically, REITs appear reluctant to issue debt when market interest rates and/or risk premiums are high, as well as when past stock performances have been strong. These market conditions however, appear to play an important role in repurchasing decisions. REITs are significantly more likely to repurchase debt when risk premiums and interest rates are high and when their stocks are highly valued. The significance of this market timing variables adds credence to our claim that repurchases are initiated to reconfigure capital structure, taking advantage of capital market conditions. The only firm characteristic variable that is significant in the repurchasing equation is asset tangibility. The positive relationship is inconsistent with the collateral value of tangible real assets that should, all else being equal, lead to reduced probability of debt repurchase due to increasing REITs' capacity to borrow more.

\subsection{Robustness Checks}

This section provides several robustness checks to the main results in Table 2. First, despite the short panel of our sample data, we re-estimated the logistic regression using GLS random effects and firm fixed effects. Second, we used quarterly change in debt ratio scaled by total assets as the dependent variable. Third, we used an alternative method to classify debt buffer variables, i.e. dummy variables equal to one for debt buffer at the top and bottom $10 \%$ of the sample. This classification allowed us to directly test our claim that the negative coefficient Debt Buffer ${ }_{t-1}{ }^{*} D^{\text {High buffer }}$ in Table 2 is driven by REITs' high buffer REITs that chose to issue equity instead of debt. 
Table 2. The Impact of Debt Buffer on Debt-Equity Choice

\begin{tabular}{|c|c|c|c|c|}
\hline \multirow[b]{2}{*}{ Explanatory variables } & \multicolumn{2}{|c|}{ Debt vs. Equity issue } & \multicolumn{2}{|c|}{$\begin{array}{c}\text { Debt reduction vs. Equity } \\
\text { repurchase } \\
\end{array}$} \\
\hline & Model 1 & Model 2 & Model 3 & Model 4 \\
\hline \multirow[t]{2}{*}{ Intercept } & 0.705 & 0.737 & $-3.853 * * *$ & $-3.760 * * *$ \\
\hline & $(0.46)$ & $(0.49)$ & $(-3.17)$ & $(-3.07)$ \\
\hline \multirow{2}{*}{ Debt Buffer ${ }_{t-1}$} & $-4.647 * * *$ & & -1.313 & \\
\hline & $(-3.82)$ & & $(-1.18)$ & \\
\hline \multirow{2}{*}{ Debt Buffer ${ }_{t-1} * D^{\text {High buffer }}$} & & $-4.418 * * *$ & & $-1.907 *$ \\
\hline & & $(-3.27)$ & & $(-1.70)$ \\
\hline \multirow{2}{*}{ Debt Buffer ${ }_{t-1} * D_{\text {buffer }}^{\text {Low }}$} & & -3.648 & & $-3.823 * *$ \\
\hline & & $(-1.49)$ & & $(-2.09)$ \\
\hline \multirow[t]{2}{*}{ Cash Holdings $_{t-1}$} & $-10.073 * *$ & $-10.251 * * *$ & 0.011 & -0.013 \\
\hline & $(-2.53)$ & $(-2.57)$ & $(0.00)$ & $(-0.00)$ \\
\hline \multirow{2}{*}{ REIT Size $_{t-1}$} & $-0.621 *$ & $-0.650 *$ & 0.380 & 0.389 \\
\hline & $(-1.77)$ & $(-1.90)$ & $(0.93)$ & $(0.93)$ \\
\hline \multirow{2}{*}{ REIT Age $_{t-1}$} & $0.515 * * *$ & $0.523 * * *$ & 0.149 & 0.119 \\
\hline & $(3.29)$ & $(3.30)$ & $(0.87)$ & $(0.68)$ \\
\hline \multirow{2}{*}{$R O A_{t-1}$} & -4.472 & -4.319 & -5.210 & -5.296 \\
\hline & $(-0.75)$ & $(-0.72)$ & $(-0.78)$ & $(-0.80)$ \\
\hline \multirow[t]{2}{*}{ Asset Tangibility $_{t-1}$} & -0.602 & -0.608 & $1.384 *$ & $1.547 *$ \\
\hline & $(-0.67)$ & $(-0.68)$ & $(1.69)$ & $(1.85)$ \\
\hline \multirow[t]{2}{*}{$M B$ ratio $_{t-1,}$} & $1.884 * *$ & $1.828 * *$ & -0.595 & -0.546 \\
\hline & $(2.10)$ & $(1.98)$ & $(-0.69)$ & $(-0.63)$ \\
\hline \multirow[t]{2}{*}{ Stock Performance $_{t,}$} & -0.823 & -0.813 & $1.685 * * *$ & $1.638 * * *$ \\
\hline & $(-1.39)$ & $(-1.38)$ & $(3.39)$ & $(3.29)$ \\
\hline \multirow[t]{2}{*}{ Term Structure $_{t}$} & -0.357 & -0.359 & $1.280 * * *$ & $1.261 * * *$ \\
\hline & $(-1.52)$ & $(-1.53)$ & $(3.60)$ & $(3.53)$ \\
\hline \multirow[t]{2}{*}{ Interest Rate $_{t,}$} & -0.062 & -0.055 & $0.468 *$ & 0.425 \\
\hline & $(-0.26)$ & $(-0.23)$ & $(1.71)$ & $(1.58)$ \\
\hline \multirow[t]{2}{*}{ Singapore REIT } & 0.480 & 0.504 & -0.566 & -0.591 \\
\hline & $(0.98)$ & $(1.06)$ & $(-1.42)$ & $(-1.47)$ \\
\hline Year \& Property Fixed Effects & Yes & Yes & Yes & Yes \\
\hline No of REITs & 51 & 51 & 52 & 52 \\
\hline No of Obs & 564 & 564 & 470 & 470 \\
\hline Pseudo $R^{2}$ & 0.10 & 0.10 & 0.11 & 0.11 \\
\hline
\end{tabular}

Notes. We estimated a logit model for REITs' debt-equity choices. The dependent variables for models 1 and 2 (3 and 4) were designed to equal one for debt issues (repurchases) and zero for equity issues (repurchases). Cases where firms issued (repurchase) both material debt and equity issues were omitted. The cut-offs for material debt/equity issues were that the issues need to be larger than US $\$ 5$ million and constitute $1 \%$ of total assets. T-statistics which appear in parentheses. *, **, *** indicate significance at the $10 \%, 5 \%$, and $1 \%$ confidence levels, respectively. 
The results reported in Panels A and B demonstrate that the main findings of this paper are robust across different econometric and empirical specifications. Our main findings that high buffer REITs tend to deviate away from their debt capacity in issuing decisions and converge at a slower pace to their debt capacity than low buffer REITs remain intact. Panel C provides strong support to our claim that the deviation from debt capacity is driven by high buffer REITs (Top $10 \%$ buffer) that chose to issue equity instead of by low buffer REITs (Bottom $10 \%$ buffer) that chose to issue debt.

Table 3. Robustness Check

\begin{tabular}{|c|c|c|c|}
\hline & $\begin{array}{l}\text { Debt vs. equity } \\
\text { issue }\end{array}$ & $\begin{array}{l}\text { Debt reduction vs. } \\
\text { Equity repurchase }\end{array}$ & $\Delta$ Debt/total assets \\
\hline Explanatory variables & Model 1 & Model 2 & Model 3 \\
\hline \multicolumn{4}{|l|}{ Panel A: Fixed effects } \\
\hline Debt Buffer ${ }_{t-1} * D^{\text {High buffer }}$ & $\begin{array}{l}-6.330 * * * \\
(-3.93)\end{array}$ & $\begin{array}{c}-1.189 \\
(-0.65)\end{array}$ & $\begin{array}{l}-0.121 * * * \\
(-3.32)\end{array}$ \\
\hline Debt Buffer ${ }_{t-1} * D^{\text {Low buffer }}$ & $\begin{array}{l}-5.796 * * \\
(-2.40)\end{array}$ & $\begin{array}{l}-3.947 \\
(-1.38)\end{array}$ & $\begin{array}{l}-0.115^{* *} \\
(-2.36)\end{array}$ \\
\hline No of Obs & 558 & 459 & 1344 \\
\hline \multicolumn{4}{|l|}{ Panel B: Random effects } \\
\hline Debt Buffer ${ }_{t-1} * D^{\text {High buffer }}$ & $\begin{array}{l}-4.419 * * * \\
(-3.90)\end{array}$ & $\begin{array}{c}-1.907 \\
(-1.52)\end{array}$ & $\begin{array}{l}-0.076 * * * \\
(-3.75)\end{array}$ \\
\hline Debt Buffer ${ }_{t-1} * D^{\text {Low buffer }}$ & $\begin{array}{l}-3.650^{*} \\
(-1.79)\end{array}$ & $\begin{array}{l}-3.823^{*} \\
(-1.70)\end{array}$ & $\begin{array}{l}-0.081^{* *} \\
(-2.24)\end{array}$ \\
\hline No of Obs & 569 & 474 & 1344 \\
\hline \multicolumn{4}{|l|}{ Panel C: Pooled } \\
\hline Top $10 \%$ buffer & $\begin{array}{l}-0.992 * * * \\
(-2.60)\end{array}$ & $\begin{array}{c}0.319 \\
(0.98)\end{array}$ & $\begin{array}{l}-0.019 * * * \\
(-5.64)\end{array}$ \\
\hline Bottom $10 \%$ buffer & $\begin{array}{c}0.192 \\
(0.50)\end{array}$ & $\begin{array}{c}0.092 \\
(0.32)\end{array}$ & $\begin{array}{l}0.014 * * \\
(2.04)\end{array}$ \\
\hline No of Obs & 564 & 470 & 1344 \\
\hline
\end{tabular}

Notes. We re-estimated our results using the same set of control variables in Table 2. Models 1-2 were estimated with the logistic regression method (fixed/random/pooled) while Model 3 was estimated with panel regression (fixed/random/pooled). T-statistics that appear in parentheses. *, **, *** indicate significance at the $10 \%, 5 \%$, and $1 \%$ confidence levels, respectively.

\subsection{Persistence (Stability) of Debt Conservatism Behavior}

This section addresses the question of whether debt conservatism behavior is persistent. Similar in spirit with Lemmon et al. (2008), we extended the lag value of capacity buffer one year at a time up to five years prior to a debt/ 
equity issuance decision. We expect the impact of capacity buffers on future capital issues/repurchases to be short-lived and weaken as we increased the lag period of the debt buffer variables. Table 4 reports the regression results using the specification in Models 2 and 4 in Table 2 for issuing and repurchasing decisions, respectively. The results show that REITs' debt-equity issue choices are influenced by their previous debt buffer up to a period of two years. The coefficient for low buffer REITs' flip to positive in year 5 indicates that debt ratios are converging. The impact of debt buffer in debt-equity repurchases was short-lived where we did not document any significant relationship beyond 1 quarter period.

Table 4. Persistency of Debt Conservatism Behavior

\begin{tabular}{|c|c|c|c|c|c|}
\hline & $\mathrm{t}=1$ year & $\mathrm{t}=2$ years & $\begin{array}{c}t=3 \\
\text { years }\end{array}$ & $\begin{array}{c}\mathrm{t}=4 \\
\text { years }\end{array}$ & $\begin{array}{c}\mathrm{t}=5 \\
\text { years }\end{array}$ \\
\hline \multicolumn{6}{|l|}{ Debt vs. Equity issue } \\
\hline Debt Buffer ${ }_{t-1} * D^{\text {High buffer }}$ & $\begin{array}{l}-3.178 * * * \\
(-3.00)\end{array}$ & $\begin{array}{l}=-2.795 * * \\
(-2.56)\end{array}$ & $\begin{array}{l}-1.023 \\
(-0.83)\end{array}$ & $\begin{array}{l}-2.841 * \\
(-1.88)\end{array}$ & $\begin{array}{l}-0.357 \\
(-0.26)\end{array}$ \\
\hline Debt Buffer ${ }_{t-1} * D^{\text {Low buffer }}$ & $\begin{array}{c}-1.034 \\
(-0.56)\end{array}$ & $\begin{array}{c}-1.509 \\
(-0.87)\end{array}$ & $\begin{array}{c}-0.132 \\
(-0.06)\end{array}$ & $\begin{array}{l}-3.904 \\
(-1.41)\end{array}$ & $\begin{array}{l}3.335 \\
(1.18)\end{array}$ \\
\hline \multicolumn{6}{|c|}{ Debt reduction vs. Equity repurchase } \\
\hline Debt Buffer ${ }_{t-1} * D^{\text {High buffer }}$ & $\begin{array}{l}-0.922 \\
(-0.64)\end{array}$ & $\begin{array}{c}-1.116 \\
(-0.77)\end{array}$ & $\begin{array}{r}0.477 \\
(0.33)\end{array}$ & $\begin{array}{c}0.929 \\
(0.58)\end{array}$ & $\begin{array}{c}0.505 \\
(0.24)\end{array}$ \\
\hline Debt Buffer ${ }_{t-1} * D^{\text {Low buffer }}$ & $\begin{array}{l}-3.663 \\
(-1.51)\end{array}$ & $\begin{array}{l}-2.419 \\
(-1.05) \\
\end{array}$ & $\begin{array}{c}3.674 \\
(1.51)\end{array}$ & $\begin{array}{c}0.727 \\
(0.25)\end{array}$ & $\begin{array}{l}-5.371 \\
(-1.24)\end{array}$ \\
\hline
\end{tabular}

Notes. We re-estimated our results with lagged value of debt buffer up to five years using the same set of control variables in Table 2 . T-statistics that appear in parentheses. *, **, *** indicate significance at the $10 \%, 5 \%$, and $1 \%$ confidence levels, respectively.

\subsection{Ruling Out Alternative Explanations}

Having provided evidence in favor of the debt conservatism behavior, we now present additional tests to rule out the alternative explanations, i.e. financial flexibility, trade-off and pecking order theories.

\subsubsection{Financial flexibility hypothesis}

Figures 2 and 3 indicate that REITs with high buffer tend to stockpile financial flexibility via unused debt facilities. This section analyses whether REITs tap into this flexibility when issuing debt. To explore this possibility, we included the interaction terms of debt buffer variables with unused debt facilities. For the financial flexibility hypothesis to be valid, we expect both the unused 
debt facilities variables and their interactions with debt buffer to be positively (negatively) and significantly related to debt issues (repurchases). Conversely, insignificance of these coefficients would indicate conservatism where REITs do not capitalize on their debt capacity despite being backed by standby credit facilities. As shown in Table 5, none of these interaction variables are found to be significant in issue and repurchase equations. The coefficients of debt buffer variables remain intact with the inclusion of these interaction variables while they turn insignificant in the repurchase equation. These findings imply that financial flexibility in the form of unused debt facilities cannot account for the debt conservatism phenomenon.

In unreported results, we also experimented with proxies to financial constraints such as cash holding, firm size, the existence of a credit rating and growth opportunities proxied by Tobin's Q ratio (Lemmon \& Zender, 2010; de Jong et al., 2011). Financially constrained firms (low cash holdings, small size, no credit rating and high growth opportunities) might be restricted in debt issuing decisions that move them towards debt capacity. If this is indeed the case, we should observe negative and significant coefficients on the interaction terms of financial constraints with debt buffer variables. Again, our key findings remained intact even after controlling for the interaction terms. The coefficients of Debt Buffer ${ }_{t-1} * D{ }^{\text {High buffer }}$ remain negative and statistically significant (1\%$5 \%$ ) while none of the Debt Buffer ${ }_{t-1} * D$ Low buffer coefficients are significant. Except for Debt Buffer ${ }_{t-1} * D$ High buffer*Tobin's $Q$, none of the debt bufferfinancial constraints' interaction terms were found to be significant. The positive coefficient was inconsistent with the implication of financial constraints. These findings collectively imply that REITs' debt conservatism behaviour are not due lack of access to external financing. It is rather a deliberate action to remain conservative.

\subsubsection{Trade-off and pecking order theory}

Following de Jong et al. (2011), we split the full sample into subsamples with debt ratios that were above and below their optimal debt ratio. We focused on regions where both theories agree/disagree to examine whether these theories are strong predictors of our data. In issuing decisions, both trade-off and pecking order theories predict firms to keep issuing debt until they reach the optimal debt ratio. Once firms are above their optimal debt limit, firms are hypothesized to issue equity according to the trade-off theory while the pecking order theory hypothesizes firms to keep raising debt until they reach their debt capacity. Empirically, these theories predict a positive debt buffer coefficient for observations below the optimal debt limit and negative (for trade-off theory) or positive (for pecking order theory) for regions above the optimal debt limit. For robustness sake, we report results using two different proxies for the optimal debt 
ratio. The first proxy is the predicted value of debt ratio regression as a function of size, age, profitability, growth opportunities and property type dummies, estimated using pooled and fixed effects estimation methods. The second proxy is industry average debt ratio measured as average debt ratio of seasoned REITs (at least two observations) in the same country of origin.

Table 5. Ruling Out Financial Flexibility Hypothesis

\begin{tabular}{|c|c|c|c|c|}
\hline \multirow[b]{2}{*}{ Explanatory variables } & \multicolumn{2}{|c|}{ Debt vs. Equity issue } & \multicolumn{2}{|c|}{$\begin{array}{l}\text { Debt reduction vs. } \\
\text { Equity repurchase }\end{array}$} \\
\hline & Model 1 & Model 2 & Model 3 & Model 4 \\
\hline \multirow[t]{2}{*}{ Intercept } & 0.410 & 1.101 & $-4.388 * * *$ & $-4.621 * * *$ \\
\hline & $(0.24)$ & $(0.70)$ & $(-2.86)$ & $(-3.75)$ \\
\hline \multirow{2}{*}{ Debt Buffer ${ }_{t-1} * D^{\text {High buffer }}$} & $-4.150 * * *$ & $-5.187 * * *$ & -1.387 & -1.598 \\
\hline & $(-3.22)$ & $(-3.71)$ & $(-1.21)$ & $(-1.22)$ \\
\hline \multirow{2}{*}{ Debt Buffer ${ }_{t-1} * D^{\text {Low buffer }}$} & -2.488 & $-4.608 *$ & $-3.660 *$ & -2.896 \\
\hline & $(-1.02)$ & $(-1.75)$ & $(-1.77)$ & $(-1.29)$ \\
\hline \multirow[t]{2}{*}{ Unused private debts } & 2.304 & & -1.941 & \\
\hline & $(0.49)$ & & $(-0.39)$ & \\
\hline \multirow{2}{*}{$\begin{array}{l}\text { Unused private debts } * \text { Debt Buffer } \\
* D^{\text {High buffer }}\end{array}$} & -5.610 & & 2.477 & \\
\hline & $(-0.37)$ & & $(0.21)$ & \\
\hline \multirow{2}{*}{$\begin{array}{l}\text { Unused private debts } * \text { Debt Buffer } \\
{ }_{t-1}^{*} D^{\text {Low buffer }}\end{array}$} & -23.267 & & 9.997 & \\
\hline & $(-0.78)$ & & $(0.34)$ & \\
\hline \multirow[t]{2}{*}{ Unused public debts } & & -1.708 & & -1.831 \\
\hline & & $(-1.22)$ & & $(-1.38)$ \\
\hline \multirow{2}{*}{$\begin{array}{l}\text { Unused public debts* Debt Buffer } \\
{ }_{t-1}^{*} D^{\text {High buffer }}\end{array}$} & & 7.826 & & 4.300 \\
\hline & & $(1.45)$ & & $(1.12)$ \\
\hline \multirow{2}{*}{$\begin{array}{l}\text { Unused public debts* Debt Buffer } \\
* D^{\text {Low buffer }}\end{array}$} & & 10.177 & & 1.928 \\
\hline & & $(1.30)$ & & $(0.28)$ \\
\hline No of Obs & 532 & 532 & 564 & 532 \\
\hline Pseudo $R^{2}$ & 0.10 & 0.11 & 0.10 & 0.11 \\
\hline
\end{tabular}

Notes. As before, we re-estimated using the same set of control variables in Table 2. T-statistics that appear in parentheses. $*, * *, * * *$ indicate significance at the $10 \%, 5 \%$, and $1 \%$ confidence levels, respectively.

The issuing results in Table 6 do not support the predictions of tradeoff/pecking order theories. The coefficients of debt buffers remain negative and significant in subsamples of high buffer REITs that are below their optimal debt 
limit across two different proxies of the optimal debt ratio. These results are against the predictions of the trade-off/pecking order theory but are consistent with that of debt conservatism. The findings that deviation from debt capacity is driven by high buffer REITs that operate below their optimal debt limit strengthens the credibility of our debt conservatism behavior in the prior section.

Table 6. Ruling Out Trade-Off and Pecking Order Theories

\begin{tabular}{|c|c|c|c|c|}
\hline \multirow[b]{2}{*}{ Explanatory variables } & \multicolumn{2}{|c|}{ Debt vs. Equity issue } & \multicolumn{2}{|c|}{$\begin{array}{l}\text { Debt reduction vs. Equity } \\
\text { repurchase }\end{array}$} \\
\hline & $\begin{array}{c}<=\text { Optimal } \\
\text { limit }\end{array}$ & $\begin{array}{l}>\text { Optimal } \\
\text { limit }\end{array}$ & $\begin{array}{c}<=\text { Optimal } \\
\text { limit }\end{array}$ & $\begin{array}{l}>\text { Optimal } \\
\text { limit }\end{array}$ \\
\hline \multicolumn{5}{|c|}{ Panel A: Pooled optimal limit } \\
\hline Debt Buffer ${ }_{t-1} * D^{\text {High buffer }}$ & $\begin{array}{l}-5.546 * * \\
(-2.08)\end{array}$ & $\begin{array}{l}-3.488^{*} \\
(-1.78)\end{array}$ & $\begin{array}{c}-2.265 \\
(-1.13)\end{array}$ & $\begin{array}{c}0.605 \\
(0.42)\end{array}$ \\
\hline Debt Buffer ${ }_{t-1} * D^{\text {Low buffer }}$ & $\begin{array}{c}-7.531 \\
(-1.45)\end{array}$ & $\begin{array}{c}-1.810 \\
(-0.68)\end{array}$ & $\begin{array}{c}-4.188 \\
(-1.09)\end{array}$ & $\begin{array}{c}-0.241 \\
(-0.12)\end{array}$ \\
\hline No of Obs & 273 & 291 & 219 & 247 \\
\hline Pseudo $R^{2}$ & 0.12 & 0.12 & 0.23 & 0.09 \\
\hline \multicolumn{5}{|c|}{ Panel B: Fixed effects optimal limit } \\
\hline Debt Buffer ${ }_{t-1} * D^{\text {High buffer }}$ & $\begin{array}{l}-4.058^{*} \\
(-1.84)\end{array}$ & $\begin{array}{l}-3.120 \\
(-1.16)\end{array}$ & $\begin{array}{c}-0.543 \\
(-0.33)\end{array}$ & $\begin{array}{c}-2.570 \\
(-1.10)\end{array}$ \\
\hline Debt Buffer ${ }_{t-1} * D^{\text {Low buffer }}$ & $\begin{array}{c}-1.507 \\
(-0.35)\end{array}$ & $\begin{array}{l}-3.922 \\
(-1.30)\end{array}$ & $\begin{array}{c}-2.371 \\
(-0.70)\end{array}$ & $\begin{array}{r}-2.460 \\
(-0.86)\end{array}$ \\
\hline No of Obs & 296 & 266 & 234 & 230 \\
\hline Pseudo $R^{2}$ & 0.12 & 0.11 & 0.23 & 0.11 \\
\hline \multicolumn{5}{|c|}{ Panel C: Industry optimal limit } \\
\hline Debt Buffer ${ }_{t-1} * D^{\text {High buffer }}$ & $\begin{array}{l}-5.149 * * \\
(-1.96)\end{array}$ & $\begin{array}{l}-2.002 \\
(-0.99)\end{array}$ & $\begin{array}{r}1.633 \\
(0.73)\end{array}$ & $\begin{array}{c}-2.437 \\
(-1.17)\end{array}$ \\
\hline Debt Buffer ${ }_{t-1} * D^{\text {Low buffer }}$ & $\begin{array}{c}-0.408 \\
(-0.07)\end{array}$ & $\begin{array}{l}-2.448 \\
(-0.78)\end{array}$ & $\begin{array}{c}2.237 \\
(0.61)\end{array}$ & $\begin{array}{l}-4.225^{*} \\
(-1.67)\end{array}$ \\
\hline No of Obs & 236 & 318 & 162 & 289 \\
\hline Pseudo $R^{2}$ & 0.11 & 0.11 & 0.24 & 0.09 \\
\hline
\end{tabular}

Notes. In accordance with de Jong et al. (2011), we split the sample into debt buffer that were above and below the optimal debt limit. As before, we re-estimated using the same set of control variables in Table 2. T-statistics that appear in parentheses. *, **, *** indicate significance at the $10 \%, 5 \%$, and $1 \%$ confidence levels, respectively.

In repurchase decisions, when debt ratio is below its optimal debt limit, the pecking order model predicts firms to repurchase debt while the trade-off theory predicts firms to increase leverage (buy back equity). When debt ratio 
exceeds its optimal debt limit, both these theories predict firms to buy back debt. Empirically, this implies either a positive (pecking order) or negative (trade-off) coefficient in the regions below optimal debt limit and a positive coefficient for both theories for the subsample above the optimal debt limit. None of the coefficients of debt buffer variables in Table 6 are significant and carry signs that suggest the validity of these theories. The sign and coefficients values, as in the full sample, suggest that high buffer REITs adjust slower than low buffer REITs towards their debt ratio.

\subsection{Does Regulatory Debt Limit Really Matter?}

In this section, we examined whether regulatory debt limit which forms the main thrust of this paper indeed matters. We did this by replacing the debt buffer variables with the actual debt ratios. As before, we defined $D$ Low leverage ( $D^{\text {High leverage }}$ ) as dummy equal to one for observations below (above) the sample median, and zero otherwise. If the debt limit is not binding, we should observe the same debt conservatism behavior we observed in Table 2, albeit in opposite signs. Specifically, the positive relationship between leverage and debt issues is driven by low leverage REITs that choose to issue equity over debt and a slower debt adjustment towards debt capacity by low leverage REITs than their high leverage counterparts.

Table 7 of Model 1 shows that high leverage REITs tend to issue more debt and are more likely to repurchase debt; findings that do not differ from debt buffer results in Table 2. However, when the samples are separated according to the level of leverage, the results are revealing. Models 2 and 3 show that ignoring debt limit leads us to conclude that the deviation in Model 1 is driven by high leverage REITs that chose to issue more debt than by low leverage REITs that issued more equity. Similarly, we conclude in the repurchase equation that low leverage firms adjust towards debt capacity by increasing debt ratio (via stock repurchases) much faster than debt reductions (via debt repurchases) made by high leverage REITs. In sum, these results suggest that debt limit indeed matters, as ignoring it leads to us to conclude that debt conservatism is of second order importance in capital structure decisions. 
Table 7. Does Regulatory Debt Limit Really Matter?

\begin{tabular}{|c|c|c|c|c|c|c|}
\hline \multirow[b]{2}{*}{ Explanatory variables } & \multicolumn{3}{|c|}{ Debt vs. Equity issue } & \multicolumn{3}{|c|}{$\begin{array}{l}\text { Debt reduction vs. Equity } \\
\text { repurchase }\end{array}$} \\
\hline & Model 1 & Model 2 & Model 3 & Model 4 & Model 5 & Model 6 \\
\hline \multirow{2}{*}{ Debt ratio $_{t-1}$} & $5.104 * * *$ & & & 1.713 & & \\
\hline & $(4.02)$ & & & (1.34) & & \\
\hline \multirow[t]{2}{*}{ Debt ratio ${ }_{t-1} * D^{\text {Low leverage }}$} & & $4.374 *$ & & & $4.768 * * *$ & \\
\hline & & $(1.94)$ & & & $(2.80)$ & \\
\hline \multirow{2}{*}{ Debt ratio ${ }_{t-1} * D^{\text {High leverage }}$} & & $4.824 * * *$ & & & $2.879 * *$ & \\
\hline & & $(3.16)$ & & & $(2.12)$ & \\
\hline \multicolumn{7}{|l|}{ Bottom $10 \%$ debt ratio } \\
\hline & & & $-1.465^{* *}$ & & & $-1.202 * *$ \\
\hline \multirow[t]{2}{*}{ Top $10 \%$ debt ratio } & & & $(-2.21)$ & & & $(-1.96)$ \\
\hline & & & $0.899 * * *$ & & & 0.223 \\
\hline Year \& Property Fixed Effects & Yes & Yes & $(3.44)$ & Yes & Yes & $(1.03)$ \\
\hline No of REITs & 51 & 51 & 51 & 52 & 52 & 52 \\
\hline No of Obs & 564 & 564 & 564 & 470 & 470 & 470 \\
\hline Pseudo $R^{2}$ & 0.10 & 0.10 & 0.10 & 0.11 & 0.11 & 0.12 \\
\hline
\end{tabular}

Notes. The regression models are exactly the same as in Table 2 except that we replaced debt buffer variables with the actual debt ratio. T-statistics that appear in parentheses. *,**,*** indicate significance at the $10 \%, 5 \%$, and $1 \%$ confidence levels, respectively.

\section{Conclusion}

This paper shows that conservatism behavior is a first-order consideration in firms' debt-equity choices. Our approach differs from most previous papers as it focuses on REITs' debt adjustment process towards/away from their debt capacity subject to individual REITs' debt buffer. We found that compared to low buffer REITs, high buffer REITs tend to issue more equity that render them to deviate further from debt capacity and move much slower towards their debt capacity through equity repurchases. These main results are robust to a battery of robustness checks and are not influenced by firms' access to capital and level of financial constraints. Taking advantage of the two debt boundaries of this study, we further show that our results are not driven by the traditional trade-off and pecking order theories and the relatively new financial flexibility hypothesis. Moreover, we illustrate that the main results are driven by high buffer REITs that operate below their optimal debt limit, a finding that could only be explained by debt conservatism behavior. We also contribute to capital structure literature by showing the importance of controlling for individual firms' debt capacity. Ignoring debt capacity leads us to wrongly conclude that firms are adopting an aggressive debt policy. 
Findings of debt conservatism for Asian REITs should not come as a surprise for two reasons. First the tax shield benefits as postulated by the tradeoff theory is absent from the REIT sector. In theory, REITs should have zero or very low leverage (Howe \& Shilling, 1988). Second, the literature on debt conservatism has shown that entrenched managers or firms with managerialfriendly corporate governance structure have preference for low debt ratio to avoid monitoring and scrutiny by the lenders (Strebulaev and Yang, 2013). Asian REITs' externally managed structure fit into this description where REIT assets are managed by an external party outside REITs. This conflict of interest is however, mitigated by the fact that the external party is owned by REIT sponsors who are also the major shareholders of REITs. ${ }^{10}$ We leave it to future research to explore factors leading to Asian REITs' preference for conservative debt policy and how this, in turn, affects their investment policy and firm valuation. ${ }^{11}$

\section{References}

Brown, D. T., \& Riddiough, T. J. (2003). Financing choice and liability structure of real estate investment trusts. Real Estate Economics, 31(3), 313-346.

Byoun, S. (2011). Financial flexibility and capital structure decision. Working Paper, Baylor University.

DeAngelo, H., DeAngelo, L., \& Whited, T. M. (2011). Capital structure dynamics and transitory debt. Journal of Financial Economics, 99(2), 235-261.

DeAngelo, H., \& Roll, R. (2015). How stable are corporate capital structures? The Journal of Finance, 2015, 70(1), 373-418.

de Jong, A., Verbeek, M., \& Verwijmeren, P. (2012). Does financial flexibility reduce investment distortions? Journal of Financial Research, 35(2), 243-259.

de Jong, A., Verbeek, M., \& Verwijmeren, P. (2011). Firms' debt-equity decisions when the static tradeoff theory and the Pecking Order Theory disagree, Journal of Banking \& Finance, 35(5), 1303-1314.

Downs, D. H., Ooi, J. T. L., Wong, W. C., \& Ong, S. E. (2016). Related party transactions and firm value: Evidence from property markets in Hong Kong, Malaysia and Singapore. Journal of Real Estate Finance and Economics, 52(4), 408-427.

Fama, E. F., \& French, K. R. (2002). Testing trade off and pecking order predictions about dividends and debt. Review of Financial Studies, 15(1), $1-33$.

Giacomini, E., Ling, D. C., \& Naranjo, A. (2017). REIT leverage and return performance: Keep your eye on the target. Real Estate Economics, 45(4), 930-978. 
Goldstein, R., Ju, N., \& Leland, H. (2001). An EBIT-based model of dynamic capital structure. The Journal of Business, 74(4), 483-512.

Graham, J. R. (2000). How big are the tax benefits of debt? The Journal of Finance, 55(5), 1901-1941.

Graham, J. R., \& Tucker, A. L. (2006). Tax shelters and corporate debt policy. Journal of Financial Economics, 81(3), 563-594.

Hardin, W. G. III., \& Hill, M. D. (2011). Credit line availability and utilization in REITs. Journal of Real Estate Research, 33(4), 507-530.

Harrison, D. M., Panasian, C. A., \& Seiler, M. J. (2011). Further evidence on the capital structure of REITs. Real Estate Economics, 39(1), 133-166.

Hennessy, C., \& Whited, T. (2005). Debt dynamics. The Journal of Finance, 60(3), 1129-1165.

Hess, D., \& Immenkotter, P. (2014). How much is too much? Debt capacity and financial flexibility. Working Paper, University of Cologne.

Hovakimian, A., Opler, T., \& Titman, S. (2001). The debt-equity choice. Journal of Financial and Quantitative Analysis, 36(1), 1-24.

Howe, J. S., \& Shilling, J. D. (1988). Capital structure Theory and REIT security offerings. The Journal of Finance, 43(4), 983-993.

Jensen, M. C. (1986). Agency costs of free cash flow, corporate finance and takeovers. American Economic Review, 76(2), 323-329.

Ju, N., Parrino, R., Poteshman, A. M., \& Weisbach, M. S. (2005). Horse and rabbits? Trade-off theory and optimal capital structure. Journal of Financial and Quantitative Analysis, 40(2), 259-281.

Leary, M., \& Roberts, M. (2010). The pecking order, debt capacity, and information asymmetric. Journal of Financial Economics, 95(3), 332355.

Lemmon, M., \& Zender, J. (2010). Debt capacity and tests of capital structure theories. Journal of Quantitative Financial Analysis, 45(5), 1161-1187.

Lemmon, M., Roberts, M. R., \& Zender, J. F. (2008). Back to the beginning: Persistence and the cross-section of corporate capital structure. Journal of Finance, 63(4), 1575-1608.

Minton, B. A., \& Wruck, K. H. (2001) Financial conservatism: Evidence on capital structure from low leverage firms. Working Paper, Ohio State University.

Modigliani, F., \& Miller, M. H. (1958). The cost of capital, corporation finance, and the theory of investment. American Economic Review, 48(3), 655669.

Modigliani, F., \& Miller, M. H. (1963). Corporate income taxes and the cost of capital: a correction. American Economic Review, 53(3), 433-443.

Molina, C. A. (2005). Are firms underleveraged? An examination of the effect of leverage on default probabilities. The Journal of Finance, 60(3), 14271460. 
Morrellec, E. (2004). Can managerial discretion explain observed leverage ratios? The Review of Financial Studies, 17(1), 257-294.

Myers, S. C. (1977). Determinants of corporate borrowing. Journal of Financial Economics, 5(2), 147-175.

Myers, S. C. (1984). The capital structure puzzle. The Journal of Finance, 39(3), 574-592.

Myers, S. C., \& Majluf, N. S. (1984). Corporate financing and investment decisions when firms have information that investors do not have. Journal of Financial Economics, 13(2), 187-221.

Nguyen, T., \& Schüßler, A. (2013). Leverage, maturities of debt and stock performance. The International Journal of Banking and Finance, 10(1), 74-93.

Ooi, T. L. J., Ong, S. E., \& Li, L. (2010). An analysis of the financing decisions of REITs: The role of market timing and target leverage. Journal of Real Estate Finance and Economics, 40(2), 130-160.

Ooi, J. T. L., Wong, W. C., \& Ong, S. E. (2012). Can bank lines of credit protect REITs against a credit crisis? Real Estate Economics, 40(2), 285-231.

Peterson, M. A. (2009). Estimating standard errors in finance panel data sets: Comparing approaches. Review of Financial Studies, 22(1), 435-480.

Riddiough, T., \& Steiner, E. (2018). Financial flexibility and manager-shareholder conflict: Evidence from REITs. Real Estate Economics (forthcoming).

Strebulaev, I. A. (2007). Do tests of capital structure theory mean what they say? The Journal of Finance, 62(4), 1747-1787.

Strebulaev, I. A., \& Yang, B. (2013). The mystery of zero-leverage firms. Journal of Financial Economics, 109(1), 1-23.

Viswanath, P.V. (1993). Strategic considerations, the pecking order hypothesis, and market reactions to equity financing. Journal of Financial and Quantitative Analysis, 28(2), 213-234.

Wong, W. C., Ong, S. E., \& Ooi, J. T. L. (2013). Sponsor backing in Asian REIT IPOs. Journal of Real Estate Finance and Economics, 46(2), 299-320. 


\section{Appendices}

\section{Appendix A: Variable Definitions}

\begin{tabular}{|c|c|}
\hline Variables & Definitions \\
\hline Debt buffer & $\begin{array}{l}\text { The difference between regulatory debt limit and actual debt } \\
\text { ratio. }\end{array}$ \\
\hline Debt ratio & Total debt scaled by total assets. \\
\hline Debt limit & $\begin{array}{l}\text { SREIT }=35 \% \text { or } 60 \% \text { (rated REITs); HREIT }=45 \% \text {; } \\
\text { MREIT }=50 \% \text {. }\end{array}$ \\
\hline Unused private debts & $\begin{array}{l}\text { Undrawn bank lines of credit \& other banking facilities (term } \\
\text { loans, trade facilities) scaled by total assets. }\end{array}$ \\
\hline Unused public debts & Untapped MTN programme scaled by total assets. \\
\hline Cash holdings & Cash \& cash equivalent scaled by total assets. \\
\hline REIT size & Book value of total assets in US\$ million. \\
\hline REIT age & Number of years since the REIT's initial public offering. \\
\hline Tobin' $Q$ & $\begin{array}{l}\text { Market value of equity minus the book } \\
\text { value of equity plus total assets } \\
\text { scaled by total assets. }\end{array}$ \\
\hline ROA & Net income scaled by total assets. \\
\hline Asset tangibility & Ratio of real estate investment scaled by total assets. \\
\hline Stock performance & $\begin{array}{l}\text { Price appreciation of individual REIT stocks over the last } 6 \\
\text { months. }\end{array}$ \\
\hline Term structure & $\begin{array}{l}\text { Difference between yields of 10-year and 1-year government } \\
\text { bonds. }\end{array}$ \\
\hline Interest rate & $\begin{array}{l}\text { 10-Year government bond yield relative to the average yield } \\
\text { over the } \\
\text { preceding four quarters. }\end{array}$ \\
\hline
\end{tabular}




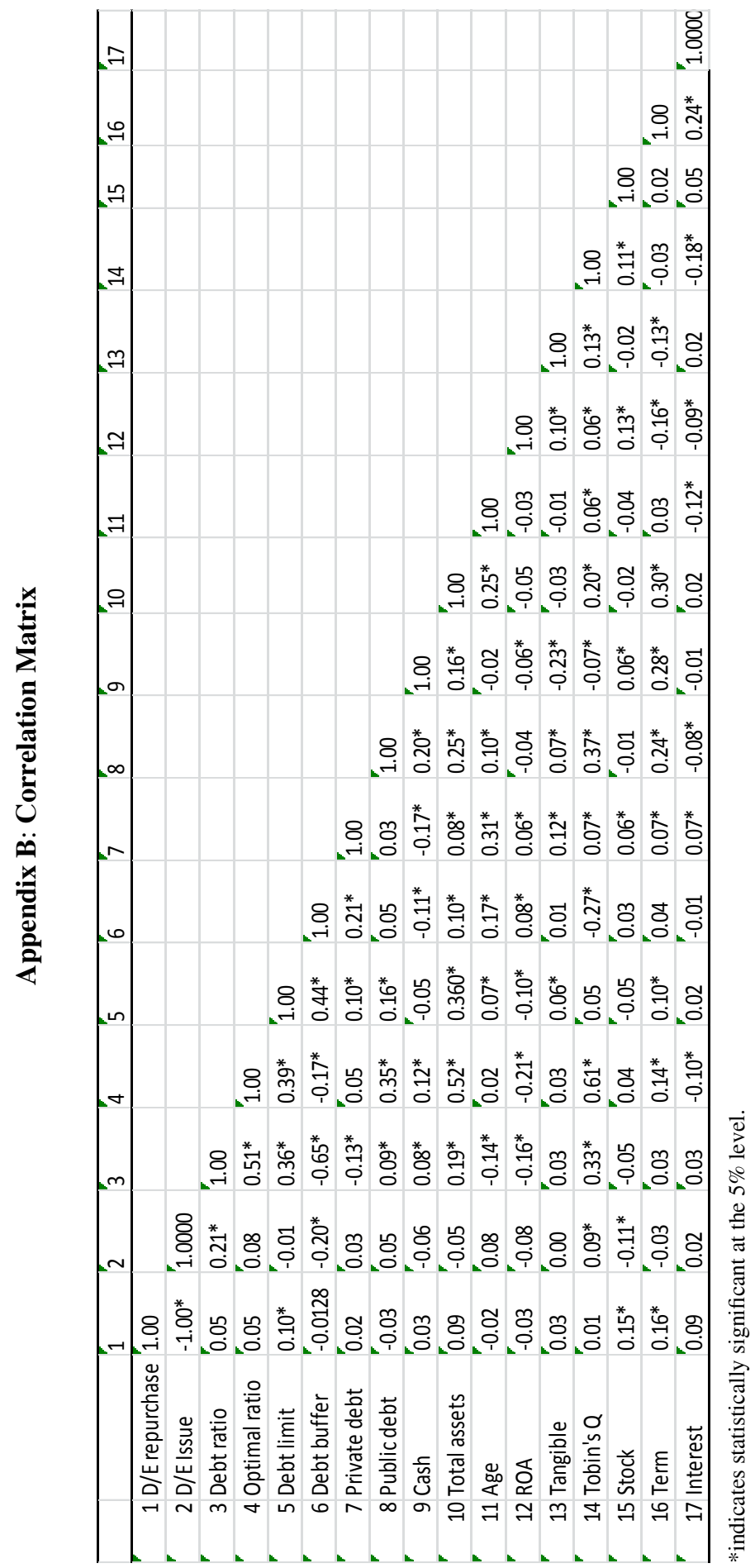




\section{End Notes}

1 Strebulaev and Yang (2013) estimated that zero leverage firms in their sample forego on average $15.6 \%$ of their market value by operating below their optimal debt ratio. Graham (2000), on the other hand, estimated a $7.3 \%$ increase in firm value if firms in their sample were leveraging up after adjustment for personal taxes.

2 Three REITs (7 firm-quarter observations) that exceeded their debt limit during the study period swiftly reduced their debt ratio in the next period.

3 "The private placement in November 2012 improved CMT's financial capacity and flexibility, with gross proceeds of approximately $\$ \$ 250.0$ million raised from the issue of 125.0 million new units. The net proceeds, together with part of the amounts raised from fixed rate notes issuances, will be used to refinance CMT's debts due in 2013. This will reduce CMT's aggregate leverage and enhance the trust's debt headroom."(CapitalMall Trust 2012 annual report)

4 Exceptions are Giacomini et al. (2017) and Ooi et al. (2010) who controlled for deviation of actual debt ratio from the optimal debt ratio in REITs' capital structure decisions. They found support for the trade-off theory where REITs that exceeded their target debt ratio tend to engage in leverage decreasing activities.

5 Briefly, the trade-off theory is based on the premise that firms trade-off between the marginal benefits of issuing debts in the form of tax-shield and the marginal costs due to bankruptcy risks (Modigliani \& Miller, (1958, 1963)). The pecking order theory, on the other hand, is based on the premise that there exists information asymmetry between managers and the market. This leads to a pecking order of securities, such that firms issue security in the order of their information sensitivity, beginning with internal funds, safe debts and reluctantly, equity when firms have used up the other two financing options (Myers \& Majluf, 1984).

6 The three main indirect approaches to compute debt capacity are firstly, the credit scoring regression approach which estimates the maximum debt ratio a firm could reach before it loses its investment grade rating (De Jong et al., 2012) or the debt ratio that causes the firm to downgrade one notch from its respective rating category, e.g. AAA to AA (Hess \& Immenkotter, 2014). The second approach is Leary and Robert's (2010) boundary of debt capacity deduced from firms' debt ratios after equity or debt issues. It is based on the pecking order theory's prediction that firms will only issue equity once they have used up their debt capacity. Thirdly, firm's optimal debt ratio as a proxy for debt capacity is estimated by running a regression of actual debt ratio on a set of trade-off variables. One main shortcoming of these indirect approaches is that the estimated debt capacity is unobservable to financial 
managers in reality. Researchers exploring the link between unused debt capacity and firms' corporate financing decisions implicitly assume that financial managers know their debt capacity ex-ante.

7 Specifically, if the unused debt facilities in the fiscal year ending in 2014 is equal to $\$ 45 \mathrm{~m}$ and year 2015 is equal to $\$ 105 \mathrm{~m}$, we assume the unused debt facilities to increase linearly by $\$ 15 \mathrm{~m}$ in each quarter such that it is equal to \$60m in Q1:2015; \$75 in Q2:2015 \$90 in Q3:2015 and \$105m in Q4:2015.

8 There is one delisted REIT (Al-Hadharah Boustead REIT) in the sample.

9 The differences in high and low buffer estimates are significant at the $10 \%$ level indicated by F-test p-value.

10 See Wong et al. (2013) and Downs et al. (2016) for a discussion of the conflict of interest in externally managed REIT structure.

11 Nguyen and Schüßler (2016) documented a negative and significant relationship between debt ratio and stock returns for firms in the UK and Germany which is consistent with the positive value of financial conservatism. 